\title{
The Headmaster's Policy in Establishing Partnerships for Improving Private Vocational Schools Quality
}

\author{
Khasanah $^{1 *}$, Imam Mawardi ${ }^{2}$, Imron $^{2}$ \\ ${ }^{1}$ Magister Manajemen Pendidikan Islam, Universitas Muhammadiyah Magelang, Magelang, Indonesia \\ ${ }^{2}$ Universitas Muhammadiyah Magelang, Magelang, Indonesia \\ *Corresponding author. Email: khasanaheni0615@gmail.com
}

\begin{abstract}
This study aims to determine the Headmaster's Policy in establishing Partnerships for Quality Improvement in Private Vocational High Schools. Data obtained through interviews, observations, and documentation. Informants were chosen purposively, and data sufficiency was used by snowball sampling technique. Research informants included the headmaster, vice headmaster, head of the expertise program, and the Business and Industrial World. The results showed that in the context of improving the quality of education, school principals as managers of educational institutions especially vocational high schools provided provisions in implementing partnership programs with partner industries, namely in the implementation of the industrial work practice program, curriculum synchronization, teaching factory, teacher internships, competency test, workforce recruitment and industrial visits conducted in the same manner, process and stage. While the difference is, not all schools have a partnership program in writing but in practice all schools apply it.
\end{abstract}

Keywords: management, development, religious character

\section{INTRODUCTION}

In the Minister of Education and Culture Regulation regarding National Standards of Vocational High School/ Vocational High School Madrasah Aliyah number 34 Year 2018 Article 1 states that Vocational High School/Madrasah Aliyah Education, hereinafter abbreviated as National Vocational High School Education concerning the education system at the level of Vocational High Schools/ Madrasah Aliyah Vocational in all jurisdictions of the Unitary State of the Republic of Indonesia in order to achieve the competence of graduates according to the needs of graduate users.

To realize this, the curriculum applied in vocational schools is designed differently from that applied in general secondary schools. Because it is focused on training students with skills in certain fields of work, the teaching material of learning systems in vocational schools is more emphasized on things that are practical or majority related to psychomotor aspects. Republic of Indonesia Government Regulation number 44 of 1997 concerning Partnerships: In article 1[1] states that partnership is the cooperation of small businesses with medium businesses and or with large businesses accompanied by coaching and development by medium businesses and or large businesses by maintaining the principle of mutual need, mutual reinforcement and winwin solution. In the face of these rapid global developments, the world of education as one of the key factors in change continues to make various efforts in improving the quality of education. The quality of education in Indonesia covers input, process, output and outcome [2]. The four components must complement each other so that the quality of education in Indonesia can improve.

Based on the background of the problem formulation above, the research objective is to describe the network of partnerships, policies and factors that support and hinder the implementation of the headmaster's policy in the Magelang District Private Vocational High School. As research conducted by Wayong on "The Relevance of Dual System Education (PSG) in Vocational Schools to the Needs of the World of Work". In its conclusion stated that the partnership between educational institutions with the business / industrial world is the main key to the success of the Dual System Education (PSG) in Vocational Schools, where the organization of education is designed, implemented and evaluated together, so that the relevance of graduate competencies to the demands of the labor market increases. The results of the pre-research interview, one of which states that the Dual System Education (PSG) that is relevant to Vocational Schools and the needs of the working world is very necessary, so that the school does, among others: understand the industrial work culture that is packaged in learning patterns, introduce schools to the existing expertise programs in the world of work, conducting promotions by distributing brochures to the world of work that contains the competencies of students, inviting relevant industries and institutions in a dialogue to inform the program and as a bridge for the implementation of internship and recruitment.

\section{RESEARCH METHODS}

This type of research is a qualitative approach, namely research conducted to understand the social phenomenon from the perspective of the culprit [3]. This research is a 
field research, which is research whose data collection is carried out in the field, such as in the community, institutions and government organizations.

Researchers used several kinds of data collection techniques to obtain the completeness of the right and valid data in this study, namely interviews, documentation, and observation. Interviews can be seen as a method of collecting data with unilateral questions and answers that are done systematically and based on the research objectives [4]. This research was conducted at three private vocational high school in Magelang Regency. Taking the research subjects using purposive sampling technique, namely the sampling technique of data sources with certain considerations.

This research uses primary and secondary data sources. Researchers conducted observations, interviews, field notes and use of school documents with data sources that directly provided data. Subjects for primary data sources were school residents which included: headmasters, teachers (head of study programs, industrial public relations officers, employees, and the Industrial Business World. secondary data sources are used to support primary data through literature studies, documentation, books, magazines, newspapers, written archives relating to the object to be examined in this study.

To obtain data, 3 techniques are used, namely 1) direct interviews with the Headmaster because the headmaster is a policy maker, Head of the Study Program (Head of Study Program) because he is responsible for mapping out the relevant partnership industries, Deputy Head of Public Relations / Industry who assists the implementation of the school headmaster's program, and the Industrial World Business as a partner. 2) Documentation, namely collecting data that is more secure through painting, copying important documents to support research, such as letters, school history, geographical location, school structure, teacher and employee data, student data and student achievement, a letter of documentation of facilities and infrastructure. Also reports on other activity programs or school personal assignments. 3) Observations namely observations made namely direct observation. The data collected in this observation is the existence of school facilities and infrastructure. In this observation, the researcher uses: (1) notes, (2) camera / android electronic devices, (3) focuses observations on relevant data, (4) adds perception material about the object being observed, and (5) clarifying observational data on informants.

The validity of the data is carried out to prove whether the research conducted is really a scientific research as well as to test the data obtained. Data validity test in qualitative research includes test, credibility, transferability, dependability, and confirmability [5].

\section{RESULTS AND DISCUSSION}

\subsection{Partnership Network in Private Vocational Schools in Magelang Regency}

Starting a partnership planning program with the world of work, both business and industry, we have followed government policies to become a school that has innovation in the medium and long term, as stated in the school's vision. Then the private Vocational High School has a clear vision to make changes in accordance with the demands of the world of education which is synchronized with the Industrial Business World. This is as revealed by Susanto who argues that innovation is the ability to be brave and responsible for making changes when needed and become a demand with changes that occur [6]. Machali and Ara write, "the headmaster as an innovator must be able to find new ideas in accordance with the development of the environment both science and technology, external, internal and school needs"[7]. From this vision, it will be elaborated in the form of work programs related to partnerships with the Industrial World of Business. The initial process undertaken by the headmaster in establishing a partnership is to develop a school program in each of the expertise competencies owned by the school which is coordinated by the head of the expertise program and / or the head of expertise competency. The deputy head of the public relations field is the vice headmaster who assists the headmaster in carrying out the task of relations with industry or society. Its activities include developing and implementing work programs, directing, fostering, leading, supervising and coordinating the implementation of specific tasks in the field of cooperative relations. Furthermore, a memorandum of understanding was made in the form of an Memorandum Of Understanding (written collaboration). The form of partnership carried out by the School are:

\subsubsection{Recruitment of workers}

In order to realize the acceleration of alumni getting a job as expected, the headmaster's policy relating to the World of Business World Industry is to conduct job recruitment. The partnership between the school and the Industrial World is expected to be directly absorbed in the world of work, because one indicator of the success of a Vocational High School is the large number of graduates who can be absorbed in the world of work.

\subsubsection{Industrial Work Practices}

The purpose of the implementation of Industrial Work Practices is as one of the requirements of the final task of industrial work practices as well as student activities to find work experience before entering the real world of work. Whereas the aim of Industrial Work Practices is to introduce students to the Industrial Business World, Grow and enhance the professional attitude needed by students to enter the business world, Increase the creative power and 
productivity of students as preparation in facing or entering the real business world, Broadening their insights and views students to the types of work in a place where students carry out industrial work practices. The same thing was stated by Indra Djati Sidi, Multiple system practice aims, first, to produce workers who have professional expertise, namely workers who have a level of ability, competence, and work ethic in accordance with the demands of employment. Second, improve and strengthen the link and match between vocational education and training institutions and the world of work. Third, improve the efficiency of the education process and training of professionally qualified workforce [8]. Fourth, give recognition and respect for work experience as part of the education process.

\subsubsection{Teacher Internship}

Teacher internships programmed by the school aim to gain direct experience in the industrial world so that they are more competent in providing understanding to students. Teacher internships are carried out by cooperating with relevant industries. The internship program for teachers is useful for overcoming the gap between competencies taught in schools, and those needed in industry. In the end of course in order to increase the professionalism of the teachers. The teacher will become a professional who will be able to deliver students to achieve a better future.

\subsubsection{Teaching Factory}

Teaching Factory learning model aims to improve the alignment of the process of delivering skills, knowledge and attitudes through thematic alignment in normative, adaptive and productive subjects. The emphasis of this learning model lies in the activities of students in understanding standards / quality, the ability to solve problems and innovate, with optimal assistance from instructors / educators who have competencies and relevant industry experience. The foregoing is in accordance with the Teaching Factory Technical Guide [9].

\subsubsection{Curriculum Synchronization}

In order for the curriculum to suit the needs of the industry, it is necessary to adjust between the school and industry so that the material contained in the curriculum with the available work fields can be used as a reference for students in achieving the required mastery of the required skills. The synchronization must be carried out together and the results become an education and training program agreed by both parties to be carried out together in a consistent manner.

The steps to synchronize the curriculum are carried out, namely holding a curriculum review workshop by inviting experts, supervisors and the Industrial World Business which aims to synchronize / adjust Core Competencies and Basic Competencies Basic competency skills are matched / synchronized with Indonesian National Work Competencies which are then integrated with standards competence. Previously the school prepared a curriculum draft and reviewed it with experts, the Industrial World Business and teachers. The revision was made after there was input from experts as well as the Industrial Business World and then it was just put in place.

\subsubsection{Industry Visits}

The purpose of holding an industry visit is:

a. So that students and teachers can see and feel directly the activities carried out in the industrial world in accordance with the profession's expertise,

b. So that students and teachers can take valuable lessons from the experience of the industry visit, so that they can stimulate and inspire the highest achievement to achieve success in their lives,

c. So that students and teachers can see and feel firsthand, that besides being important it means to improve the competency skills in accordance with their profession, it is also very necessary to practice and familiarize life with the provision of attitude abilities (attitudes, behavior, and high discipline) that are required owned by every student,

d. Strengthening relations with partner institutions to develop more concrete cooperation up to the level of Memorandum of Understanding on industry visits, training for teachers in the industry, job vacancy information and possible assistance of equipment / components produced by industry.

\subsubsection{Expertise Competency Test}

To measure the achievement of students' competencies, a competency test is carried out by involving the Industrial Business World as examiners or evaluators. The implementation of the Expertise Competency Test aims to measure the achievement of student competencies at a certain level according to the expertise competencies pursued during the learning period at the Vocational High School. The Expertise Competency Test is carried out by an education unit in the form of a practical test that examines aspects of knowledge, skills and attitudes.

The results showed that in order to improve the quality of private Vocational High Schools implemented a partnership program with industry partners in the implementation of the Industrial Work Program, Curriculum Synchronization, Teaching Factory, Teacher Internships, Competency Test, Workforce Recruitment and Industrial Visits by means of, process and the same stages. While the difference is, not all schools have a partnership program in writing but in practice all schools apply it.

\subsection{Supporting and inhibiting factors for implementing partnerships}

Factors that support the implementation of partnerships with the Industrial Business World, namely the existence of programs and systematic planning, the availability of 
business and industrial sectors. implementation of link and match to fulfill learning in school.

experts, skilled and adequate equipment and funds, the condition of school organizations that allow to improve the activities of school relations with industry, the commitment of school headmasters with The industry is supported by awareness of the importance of establishing partnerships with industry, support from relevant agencies is very strong to make the spirit of establishing partnerships, the active role of school headmasters in improving educational efforts through partnerships and the existence of learning programs that implement links and match so that the learning process runs well. This is as explained in one of the government policies for the success of the Vocational High School Revitalization program, namely Regulation of the Minister of Industry (Permenperin) number 32017 [10]. Philosophically, link and match imply insight into the development of Human Resources, the future, quality and excellence, professionalism value added and efficiency. Link and match involve an interactive process with appropriate results. Theoretically, link and match refer to the link and link competency of graduates from the world of education in order to be accepted and match the needs of the workforce. From this statement, it can be seen that the education world should be able to establish cooperation with all parties related to the world of work, such as industry.

Factors which become obstacles in the implementation faced in establishing partnership are:

a. Weak school resources and human resources in managing partnerships with the Industrial Business World. Educational strategies are more input oriented policies which tend to be regulated by the bureaucracy at the central level so that the process of building quality is less innovative and weak in partnership empowerment.

b. School institutions still use the old management pattern which is considered less effective and efficient in managing partnerships.

c. Decentralized school management is hampered by human resource problems that can drive the quality of education.

d. Leadership style that is not in accordance with the strategic efforts of the partnership as a quality resource.

e. The large number of programs planned by the school headmaster or head of the study program has a significant financial impact.

\section{CONCLUSION}

To improve the quality of education, private vocational high schools in Magelang regency have established a school partnership network with the industrial world both in the
The Headmaster's policy in establishing partnerships with the Industrial Business World is evidenced by the program Teaching Factory, Industrial Work Practices, Expertise Competency Test, Curriculum Synchronization, Manpower Recruitment, and Industrial Visits.

\section{REFERENCES}

[1] Peraturan Pemerintah Republik Indonesia Nomor 44 Tahun 1997 tentang Kemitraan.

[2] Depdiknas. Manajemen Peningkatan Mutu Pendidikan Berbasis Sekolah (Buku). Jakarta, 2001

[3] Sarjono, dkk. Panduan Penulisan Skripsi Jurusan Pendidikan Agama Islam. Yogyakarta: Fakultas Tafbiyah UIN Sunan Kalijaga, 2008

[4] Hadi, Sutrisno. Metode Penelitian Pendidikan. Yogyakarta: Andi Offset, 2013

[5] Sugiyono. (2006). Metode Penelitian Kualitatif. Bandung: Alfabeta

[6] Susanto, Ahmad. Manajemen Peningkatan Kinerja Guru, Jakarta: Prenadamedia Group, 2018

[7] Machali, Imam and Ara Hidayat. The Handbook of Education Management. Jakarta: Prenadamedia Group, 2018

[8] Sidi, I. Djati. Menuju Masyarakat Belajar, Menggagas Paradigma Baru Pendidikan. Jakarta: Paramadina, 2001

[9] Kementrian Perindustrian. Panduan Teknis Teaching Factory, Published by the Deutsche Gesellschaft für Internationale Zusammenarbeit (GIZ) GmbH, 2017

[10] Peraturan Menteri Perindustrian Nomor 3 tahun 2017

[11] Bambang Ixtiarto dan Budi Sutrisno. Kemitraan Sekolah Menengah kejuruan dengan Dunia Usaha dan Dunia Industri. Jurnal Pendidikan Ilmu Sosial. 26 (1), 57-69, 2016. planned by the Vocational High School, Teacher Internship, 